\title{
Observation of 2-methyltetrols and related photo-oxidation products of isoprene in boreal forest aerosols from Hyytiälä, Finland
}

\author{
I. Kourtchev ${ }^{1}$, T. Ruuskanen ${ }^{2}$, W. Maenhaut ${ }^{3}$, M. Kulmala ${ }^{2}$, and M. Claeys ${ }^{1}$ \\ ${ }^{1}$ Department of Pharmaceutical Sciences, University of Antwerp (Campus Drie Eiken), Universiteitsplein 1, 2610 Antwerp, \\ Belgium \\ ${ }^{2}$ Department of Physical Sciences, Division of Atmospheric Sciences, University of Helsinki, P.O. Box 64, Gustaf \\ Hällströminkatu 2, 00014 Helsinki, Finland \\ ${ }^{3}$ Department of Analytical Chemistry, Institute for Nuclear Sciences, Ghent University, Proeftuinstraat 86, 9000 Gent, \\ Belgium
}

Received: 16 March 2005 - Published in Atmos. Chem. Phys. Discuss.: 9 May 2005

Revised: 15 August 2005 - Accepted: 26 September 2005 - Published: 21 October 2005

\begin{abstract}
Oxidation products of isoprene including 2methyltetrols (2-methylthreitol and 2-methylerythritol), 2methylglyceric acid and triol derivatives of isoprene (2methyl-1,3,4-trihydroxy-1-butene (cis and trans) and 3methyl-2,3,4-trihydroxy-1-butene) have been detected in boreal forest $\mathrm{PM}_{1}$ aerosols collected at Hyytiälä, southern Finland, during a 2004 summer period, at significant atmospheric concentrations (in total $51 \mathrm{ng} \mathrm{m}^{-3}$ in summer versus $0.46 \mathrm{ng} \mathrm{m}^{-3}$ in fall). On the basis of these results, it can be concluded that photo-oxidation of isoprene is an important atmospheric chemistry process that contributes to secondary organic aerosol formation during summer in this conifer forest ecosystem. In addition to isoprene oxidation products, malic acid, which can be regarded as an intermediate in the oxidation of unsaturated fatty acids, was also detected at high concentrations during the summer period $\left(46 \mathrm{ng} \mathrm{m}^{-3}\right.$ in summer versus $5.2 \mathrm{ng} \mathrm{m}^{-3}$ in fall), while levoglucosan, originating from biomass burning, became relatively more important during the fall period $\left(29 \mathrm{ng} \mathrm{m}^{-3}\right.$ in fall versus $10 \mathrm{ng} \mathrm{m}^{-3}$ in summer). Pinic acid, a major photo-oxidation product of $\alpha$ pinene in laboratory experiments, could only be detected at trace levels in the summer samples, suggesting that further oxidation of pinic acid occurs and/or that different oxidation pathways are followed. We hypothesize that photo-oxidation of isoprene may participate in the early stages of new particle formation, a phenomenon which has been well documented in the boreal forest environment.
\end{abstract}

Correspondence to: M. Claeys

(magda.claeys@ua.ac.be)

\section{Introduction}

The chemical composition of secondary organic aerosols is a topic of considerable interest in atmospheric chemistry since it largely determines the physico-chemical properties of the aerosol such as hygroscopicity, light absorbance/reflectance, and particle formation and growth. Our knowledge on the organic chemical composition of atmospheric aerosols is in general rather limited; only about $10-20 \%$ of the organic matter has been characterized at the molecular level (e.g., Rogge et al., 1993; Kubátová et al., 2002). On the one hand, the organic fraction of atmospheric aerosol consists of small extractable organic molecules, which can provide important information on aerosol sources and source processes (Zheng et al., 2002). On the other hand, organic aerosol is also made up of primary biological particles (fungal spores, pollen and microorganisms) (Matthias-Maser and Jaenicke, 1995; Bauer et al., 2002a) and polar oligomeric/polymeric humic-like substances (Havers et al., 1998; Krivacsy et al., 2001), which have multiple sources (biomass burning, photooxidation of anthropogenic and biogenic volatile organic compounds (VOCs)) and for which characterization at the molecular level is technically more difficult.

It has been well established that photo-oxidation products of monoterpenes (e.g., $\alpha$ - and $\beta$-pinene), which are biogenic VOCs emitted mainly by terrestrial vegetation, contribute to the aerosol budget (e.g., Hoffmann et al., 1997; Kavouras et al., 1998 and 1999). In contrast, it has been assumed that the much larger emissions of isoprene, estimated at about $500 \mathrm{Tg}$ per year on a global scale (Guenther et al., 1995), do not result in secondary organic aerosol (SOA) formation in the atmosphere (Pandis et al., 1991). However, evidence from both field and laboratory experiments has been obtained in

(C) 2005 Author(s). This work is licensed under a Creative Commons License. 
the last three years for isoprene contributing to SOA formation. Claeys et al. (2004a) identified two diastereoisomeric 2-methyltetrols, i.e., 2-methylthreitol and 2-methylerythritol, in Amazonian rain forest aerosols, and proposed on the basis of their isoprene skeleton that they are formed through photo-oxidation of isoprene. In a recent smog chamber study by Edney et al. (2005), it was shown that the 2-methyltetrols can be generated in irradiated isoprene $/ \mathrm{NO}_{\mathrm{x}} / \mathrm{SO}_{2} /$ air mixtures and that sulfuric acid plays a major role in their formation. Results from a recent field experiment conducted at K-puszta, Hungary, during the summer of 2003 established that the 2-methyltetrols exhibit a diel pattern with the highest concentrations during day-time, which can be regarded as supporting evidence for their fast photochemical formation from locally emitted isoprene (Ion et al., 2005). Other studies indicating a role for isoprene in SOA formation are the smog chamber study by Jang et al. (2002), who demonstrated that acidic seed aerosol enhances SOA formation from isoprene, and the laboratory study by Limbeck et al. (2003), who showed the formation of humic-like substances from isoprene/ozone mixtures in the presence of sulfuric acid. Furthermore, results from a field study carried out by Matsunaga et al. (2003) at a northern Japanese mixed forest indicate that semi-volatile oxidation products of isoprene, i.e., glycolaldehyde and hydroxyacetone, are present at significant concentrations in forest aerosol.

So far, organic aerosol composition studies conducted at conifer forest sites have focused on monoterpene oxidation products (Kavouras et al., 1998 and 1999; Yu et al., 1999; Pio et al., 2001), since it is known that monoterpene emissions are important in these environments (Jobson et al., 1994; Lamanna and Goldstein, 1999; Hakola et al., 2000) and monoterpenes result in high SOA yields in laboratory experiments (Griffin et al., 1999). We present here the first measurements of isoprene-derived aerosol components in $\mathrm{PM}_{1}$ aerosols from Hyytiälä, southern Finland, and show that photo-oxidation of isoprene is an important atmospheric chemistry process that contributes to secondary aerosol formation at this boreal forest site.

\section{Instrumentation}

\subsection{Site description}

The boreal forest measurement station SMEAR (System for Measurement of forest Ecosystem and Atmospheric Relationships) II at Hyytiälä (southern Finland, $61^{\circ} 51^{\prime} \mathrm{N}$, $24^{\circ} 17^{\prime} \mathrm{E}, 170 \mathrm{~m}$ a.s.1.) was built to provide a crossdisciplinary co-operation between atmospheric, soil and forest ecological studies on fluxes of different compounds in Scots pine forest. The forest around the station is dominated by conifers (Pinus sylvestris and Picea abies) with some aspen and birch. The site represents a rural background site; however, pollution may be caused by the station buildings
(0.5 km away) and the city of Tampere (63 km southwest). The site is described in more detail by Vesala et al. (1998), and instrumentation by Kulmala et al. (2001).

\subsection{Aerosol sampling}

Samples were collected by drawing air through a Dekati PM10 impactor at a flow rate of $35 \mathrm{~L} \mathrm{~min}^{-1}$. Three 48 -h samples were taken during the summer of 2004: between 24 and 26, 26 and 28 of July, as well as between 4 and 6 August. The sampling time was reduced to $12 \mathrm{~h}$ for fall samples that were taken between 22 September and 8 October. In the Dekati impactor aerosols larger than $1 \mu \mathrm{m}$ deposit to films that were greased with Apiezon L (M\&I Materials Ltd., Manchester, UK), a petroleum-based product with melting point between 42 and $52^{\circ} \mathrm{C}$, to prevent bouncing of impacting aerosols. Aerosols smaller than $1 \mu \mathrm{m}$ pass through unaffected and were collected on quartz fiber filters at the bottom of the impactor. The quartz fiber filters were prebaked for $12 \mathrm{~h}$ at $500^{\circ} \mathrm{C}$ to remove possible organic contaminants. The pre-baked quartz filters and aerosol samples were handled in a laminar flow chamber and stored in Petri slides that were kept in a refrigerator prior to analysis. Blank filters, treated in the same way as the samples, were used as field blanks.

\subsection{Aerosol analysis}

Three filter samples from the summer period (48-h samplings), ten filter samples from the fall period (12-h samplings), and five field blanks were analyzed. Parts of the quartz fiber filters $\left(1.5 \mathrm{~cm}^{2}\right)$ were first subjected to analysis for organic carbon (OC) and elemental carbon (EC) by a thermal-optical transmission (TOT) technique (Birch and Cary, 1996), which delivers the OC and EC mass in $\mu \mathrm{gC}$. The filters were subsequently analyzed for polar organic marker compounds by gas chromatography/mass spectrometry (GC/MS) using a derivatization procedure that converts carboxyl and hydroxyl functions to trimethylsilyl (TMS) derivatives. The analytical procedure was adapted from a method that has been previously reported (Pashynska et al., 2002). A part of the quartz fiber filter ( $1 / 4$ for the summer samples and the whole filter for the fall samples) was placed in a $25 \mathrm{~mL}$ Pyrex glass flask and spiked with internal recovery standards, i.e., methyl- $\beta$-D-xylanopyranoside $(420 \mathrm{ng})$ and deuterated $\left(\mathrm{d}_{3}\right)$ malic acid (733 ng) which were applied in methanolic solutions $\left(1 \mathrm{mg} \mathrm{mL}^{-1}\right)$. After drying the spiked filter part for $30 \mathrm{~min}$, it was extracted three times with $20 \mathrm{ml}$ of dichloromethane-methanol $(80: 20, \mathrm{v} / \mathrm{v})$ under ultrasonic agitation for $30 \mathrm{~min}$. The extracts were combined, reduced in volume with a rotary evaporator $\left(213 \mathrm{hPa}, 30^{\circ} \mathrm{C}\right)$ to approximately $1 \mathrm{~mL}$ and filtered through a Teflon filter $(0.45 \mu \mathrm{m})$. Thereafter, the filtrate was dried under nitrogen and dissolved in $200 \mu \mathrm{L}$ of dichloromethane-methanol $(50: 50, \mathrm{v} / \mathrm{v})$. The final solution was divided into two parts. One part was left in a refrigerator 
at $4^{\circ} \mathrm{C}$ for eventual further analysis. Another part was transferred to a $3 \mathrm{~mL}$ silylation vial and evaporated under nitrogen. The residue was derivatized by addition of $25 \mathrm{~mL}$ of $\mathrm{N}$-Methyl- $\mathrm{N}$-trimethylsilyltrifluoroacetamide containing $1 \%$ trimethylchlorosilane (MSTFA+1\% TMCS) and $15 \mathrm{~mL}$ pyridine, and the reaction mixture was heated for $1 \mathrm{~h}$ at $70^{\circ} \mathrm{C}$. An aliquot $(1 \mu \mathrm{L})$ of the derivatized sample was immediately analyzed by GC/MS.

Qualitative and quantitative analyses were performed with a GC/MS system consisting of a TRACE GC2000 gas chromatograph and using a Rtx ${ }^{\circledR}-5 \mathrm{MS}$ fused silica capillary column (Crossbond ${ }^{\circledR} 5 \%$ diphenyl, 95\% dimethyl polysiloxane, $0.25 \mu \mathrm{m}$ film thickness, $30 \mathrm{~m} \times 0.25 \mathrm{~mm}$ i.d.) (Restec Corp., PA, USA). The gas chromatograph was interfaced to a Polaris Q ion trap mass spectrometer fitted with an external electron ionization source (ThermoFinnigan, San Jose, CA, USA). Helium was used as carrier gas at a flow rate of $1.2 \mathrm{~mL} \mathrm{~min}^{-1}$. The temperature program was as follows: isothermal hold at $50^{\circ} \mathrm{C}$ for $5 \mathrm{~min}$, temperature ramp of $3^{\circ} \mathrm{C} \mathrm{min}^{-1}$ up to $200^{\circ} \mathrm{C}$, isothermal hold at $200^{\circ} \mathrm{C}$ for $2 \mathrm{~min}$, temperature ramp of $30^{\circ} \mathrm{C} \mathrm{min}^{-1}$ up to $310^{\circ} \mathrm{C}$; and isothermal hold at $310^{\circ} \mathrm{C}$ for $2 \mathrm{~min}$. The total analysis time was $61 \mathrm{~min}$. The injections were performed in the splitless mode. The mass spectrometer was operated in the electron ionization (EI) mode at an electron energy of $70 \mathrm{eV}$ and an ion source temperature of $200^{\circ} \mathrm{C}$. For qualitative analysis, the full scan mode was used in the mass range $m / z$ 50-650. For quantitative analysis, the instrument was operated in the selected ion monitoring (SIM) mode using an ion dwell time of $25 \mathrm{~ms}$. The selected ions were at $m / z 204$ and 217 for the internal recovery standard (IS), methyl- $\beta$-D-xylanopyranoside, and for levoglucosan, $\mathrm{m} / \mathrm{z}$ 219 and 277 for the 2-methyltetrols (2-methylthreitol and 2-methylerythritol), $\mathrm{m} / \mathrm{z} 233$ and 307 for malic acid, $\mathrm{m} / \mathrm{z}$ 236 and 310 for deuterated $\left(\mathrm{d}_{3}\right)$ malic acid, $\mathrm{m} / z 217$ and 319 for arabitol and mannitol, and $m / z 231$ for the alkene triol derivatives of isoprene (2-methyl-1,3,4-trihydroxy-1butene (cis and trans) and 3-methyl-2,3,4-trihydroxy-1butene). Quantification of 2-methylglyceric and glyceric acids was done in the full scan mode. Data were acquired using Xcalibur software, version 1.2. For the quantification of levoglucosan, mannitol, arabitol, and glyceric acid, calibration curves were constructed by analyzing aliquots of a stock solution of authentic standards that had been processed with the method described above. Malic acid was calculated using the response factor of deuterated $\left(\mathrm{d}_{3}\right)$ malic acid. For assessing the amounts of compounds for which no pure reference compounds were available, the response factors of the following compounds were used: erythritol for the 2methyltetrols and the alkene triol derivatives of isoprene, and glyceric acid for 2-methylglyceric acid.

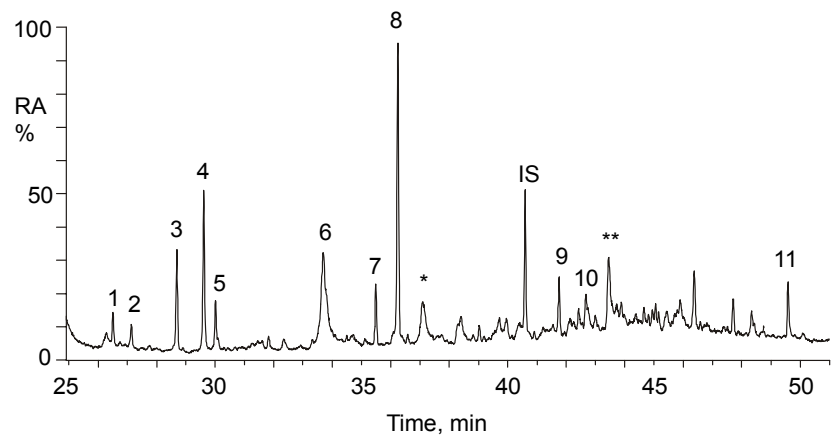

Fig. 1. GC/MS total ion chromatogram obtained on a summer aerosol sample (4-6 August).

(1) 2-methylglyceric acid; (2) glyceric acid; (3) cis-2-methyl1,3,4-trihydroxy-1-butene; (4) 3-methyl-2,3,4-trihydroxy-1-butene; (5) trans-2-methyl-1,3,4-trihydroxy-1-butene; (6) malic acid $\left(+\mathrm{d}_{3}\right.$ malic acid); (7) 2-methylthreitol; (8) 2-methylerythritol; (9) levoglucosan; (10) arabitol, (11) mannitol; (*) and (**) compounds due to photo-oxidation of $\alpha$-pinene.

\section{Results and discussion}

\subsection{Characterization of polar organic compounds}

Figure 1 presents the GC/MS total ion chromatogram (TIC) obtained for a summer aerosol sample collected during a warm period (4-6 August 2004). The chemical structures of the identified polar organic compounds are given in Fig. 2. In the following discussion, we will first focus on the compounds that can be explained by photo-oxidation of isoprene. The electron ionization (EI) mass spectra obtained for the compounds that were characterized as isoprene oxidation products $(1,3,4,5,7$ and 8$)$ are presented in Fig. 3. All compounds were characterized on the basis of their EI mass spectra and comparison with those of authentic reference compounds or reported mass spectral data (Claeys et al., 2004b; Wang et al., 2005). Peaks 7 and 8 correspond to the 2-methyltetrols, 2-methylthreitol and 2-methylerythritol, which have first been reported in $\mathrm{PM}_{2.5}$ aerosols from the Amazonian rain forest (Claeys et al., 2004a). Since the 2methyltetrols have retained the isoprene skeleton, their formation has been explained through photo-oxidation of isoprene, which is emitted in large amounts by the tropical forest vegetation. The GC/MS TIC results obtained for the summer $\mathrm{PM}_{1}$ aerosol samples show that the 2-methyltetrols are also major aerosol components at Hyytiälä (Fig. 1). This finding may be surprising since this site is dominated by conifers (Pinus sylvestris and Picea abies); however, isoprene emissions at Hyytiälä are relatively high during the summer months, corresponding to about one third of those of the monoterpenes (Hakola et al., 2003), and can thus explain the formation of the 2-methyltetrols through photo-oxidation of isoprene in this forest ecosystem. These high summer time isoprene emissions at Hyytiälä are due to contributions from deciduous trees and isoprene-emitting conifers such as Picea 
<smiles>CC(O)(CO)C(=O)O</smiles><smiles>C/C(=C/O)C(O)CO</smiles>

$\mathrm{HO}$

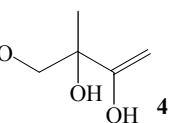<smiles>O=C(O)CC(O)C(=O)O</smiles><smiles>CC(O)(CO)C(O)CO</smiles><smiles>OC[C@@H](O)[C@@H](O)[C@H](O)[C@H](O)CO</smiles>

Fig. 2. Chemical structures of the compounds detected in $\mathbf{P M}_{1}$ summer aerosol samples collected at Hyytiälä: (1) 2-methylglyceric acid; (2) glyceric acid; (3) cis-2-methyl-1,3,4-trihydroxy-1-butene; (4) 3-methyl-2,3,4-trihydroxy-1-butene; (5) trans-2-methyl-1,3,4trihydroxy-1-butene; (6) malic acid; (7) 2-methylthreitol; (8) 2methylerythritol; (9) levoglucosan; (10) arabitol and (11) mannitol.

abies (Janson and de Serves, 2001; Hakola et al., 2003) and possibly also to contributions from vegetation of the nearby wetlands (Janson and de Serves, 1998; Janson et al., 1999). It is worth mentioning that important emissions of isoprene have also been reported for other conifer forest sites, e.g., above a Sierra Nevada ponderosa pine plantation in California, USA, where isoprene likely originates from a nearby oak forest, was the most important single compound emitted and accounted for about one third of the detected $\mathrm{C}_{2}-\mathrm{C}_{10}$ VOCs during a 1997 summer period (Lamanna and Goldstein, 1999). Peaks 3, 4 and 5 correspond to triol derivatives of isoprene, i.e. 2-methyl-1,3,4-trihydroxy-1-butene (cis and trans) and 3-methyl-2,3,4-trihydroxy-1-butene, which in a recent study (Wang et al., 2005) have been tentatively characterized in $\mathrm{PM}_{2.5}$ aerosols from the Amazonian rain forest. The latter oxygenated isoprene derivatives have been explained through acid-catalyzed ring opening of epoxydiol derivatives of isoprene and possibly form in ambient atmospheric conditions (e.g., a low relative humidity) that do not allow their complete hydrolysis to 2-methyltetrols. Peak 1 was characterized as 2-methylglyceric acid, which has been first reported in rural $\mathrm{PM}_{2.5}$ aerosols from K-puszta, Hungary (Claeys et al., 2004b). This dihydroxymonocarboxylic acid, which has retained part of the isoprene skeleton, is believed to be a secondary/tertiary oxidation product of isoprene formed by further oxidation of methacrolein (Pierrotti et al., 1990) and methacrylic acid (Chien et al., 1998), which are gas-phase oxidation products of isoprene. Peak 2 was identified as glyceric acid, a dihydroxymonocarboxylic acid, which has previously been reported in Amazonian aerosols (Graham et al., 2002) and possibly originates from further oxidation of acrylic acid, another gas-phase oxidation product of isoprene (Chien et al., 1998). Other sources for glyceric acid, however, cannot be excluded and may include oxidation of other VOCs and biomass burning.

In addition to compounds that can be related to photooxidation of isoprene, other compounds detected in the $\mathrm{PM}_{1}$ summer aerosols from Hyytiälä, Finland, with TIC intensities comparable to that of 2-methylthreitol (7), include malic acid (6), levoglucosan (9), arabitol (10) and mannitol (11) (Figs. 1 and 2). Malic acid (6) is believed to be an intermediate in the oxidation of unsaturated fatty acids (Kawamura and Ikushima, 1993; Kawamura and Sakaguchi, 1999; Neusüss et al., 2000). However, there are likely other sources for malic acid, both anthropogenic and biogenic ones. Hjorth et al. (2002) showed in laboratory experiments that malic acid can be produced from benzene through intermediate phenol formation by $\mathrm{OH}$ radical-initiated oxidation. Claeys et al. (2004a) suggested that malic acid may arise from oxidation of biogenic VOCs other than unsaturated fatty acids that are emitted by forest vegetation. Brook et al. (2004) showed that malic acid is a suitable marker for SOA in urban aerosols from Toronto, Canada, and found that it is correlated with the aerosol acidity. Levoglucosan (9) is an anhydro derivative of glucose which is formed through pyrolysis of cellulose at temperatures above $300^{\circ} \mathrm{C}$ (Shafizadeh, 1984) and is an excellent organic marker for biomass smoke ( $\mathrm{Si}$ moneit, 2002). Levoglucosan could be detected in the summer aerosol samples and became a dominant organic species in the fall samples, indicating that there is wood burning taking place at or close to the forest station in Hyytiälä, likely for domestic heating purposes. Arabitol (10) and mannitol (11) are believed to be from fungal origin (Bieleski, 1982) and are known to be mainly associated with the coarse size fraction of forest aerosols (Graham et al., 2003; Claeys et al., 2004a). It is noted that arabitol and mannitol are detected with significant intensities in the GC/MS TICs of the $\mathrm{PM}_{1}$ samples (Fig. 1). Similar results were reported by Carvalho et al. (2003) for size-fractionated aerosol samples collected at the same site, who found that mannitol predominantly appeared in the fine mode at $\mathrm{D}_{p}<0.39 \mu \mathrm{m}$, in contrast to samples collected at a rural meadow site in Melpitz, Germany, where mannitol clearly peaked in the coarse mode between 1.3 and $4.2 \mu \mathrm{m}$ which is the size range for spores of typical airborne fungal strains (i.e., Cladosporium, Penicillium and Fusarium strains) (Bauer et al., 2002b). Graham et al. (2003) observed arabitol and mannitol in both the fine $(<2.5 \mu \mathrm{m} \mathrm{AD})$ and coarse $(>2.5 \mu \mathrm{m} \mathrm{AD})$ size fractions of Amazonian forest aerosols and attributed the presence of the sugar polyols in the fine fraction to fungal fragments.

Pinic acid, a major oxidation product of $\alpha$-pinene in laboratory experiments (Hoffmann et al., 1997), could only be detected at trace levels in the $\mathrm{PM}_{1}$ samples (results not shown), suggesting that photo-oxidation pathways leading 

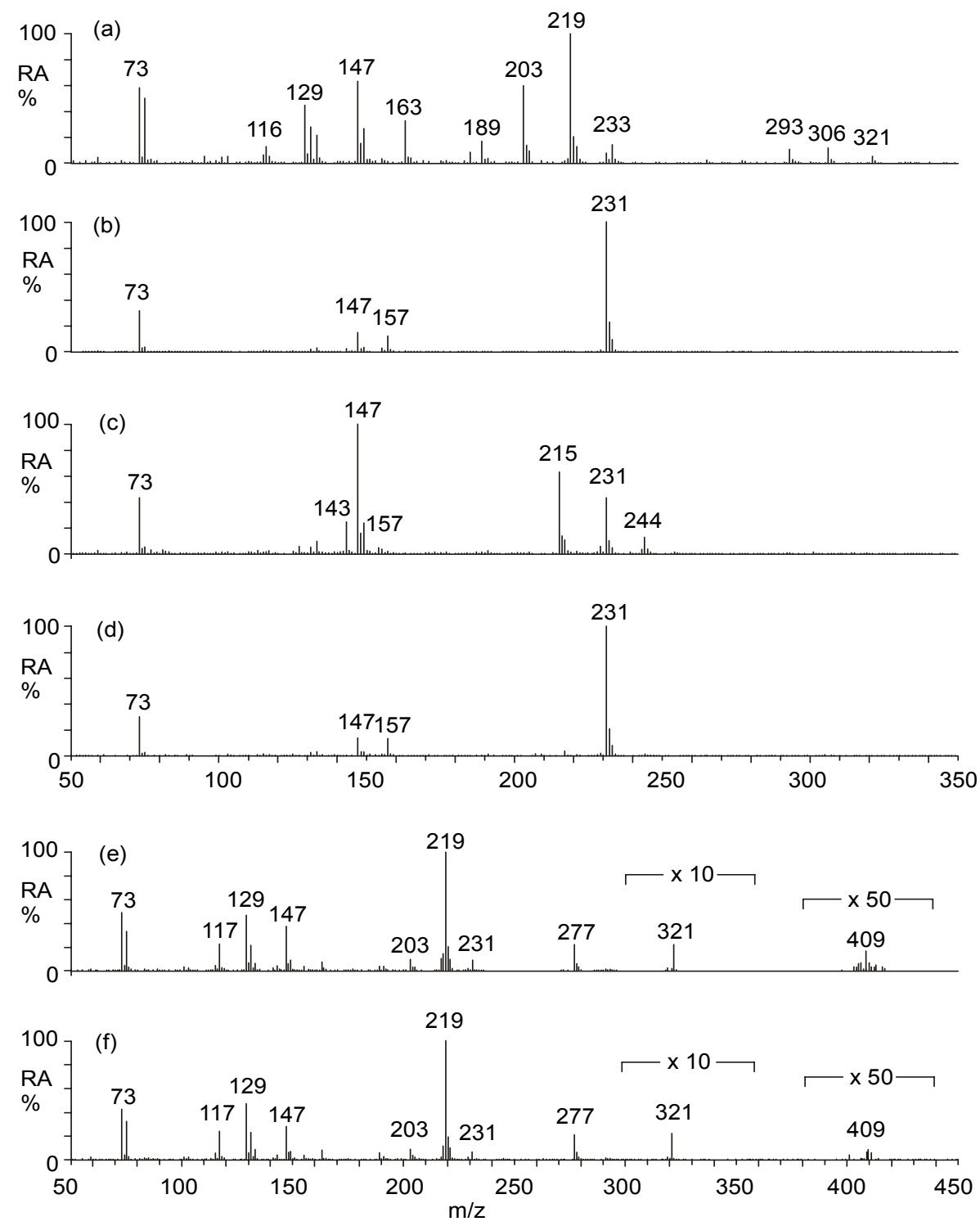

Fig. 3. EI ion trap mass spectra obtained for the TMS derivatives of compounds identified as: (a) 2-methylglyceric acid; (b) cis-2-methyl1,3,4-trihydroxy-1-butene; (c) 3-methyl-2,3,4-trihydroxy-1-butene; (d) trans-2-methyl-1,3,4-trihydroxy-1-butene; (e) 2-methylthreitol; (f) 2-methylerythritol.

to secondary or higher order oxidation products have to be considered for this forest site during summer. This result is in agreement with a recent report on a field campaign carried out in August 2001 at the same site (Boy et al., 2004), which only showed low concentrations of pinic acid (max $5 \mathrm{ng} \mathrm{m}^{-3}$ ). Further research on the characterization of $\alpha$ pinene oxidation products in $\mathrm{PM}_{1}$ aerosols from Hyytiälä, Finland, is currently in progress in our laboratory. The compounds marked with * and ** in the GC/MS TIC chromatogram shown in Fig. 1 are believed to be photo-oxidation products of $\alpha$-pinene; the compound marked $*$ corresponds to an unknown hydroxydicarboxylic acid of which the chemical structure is under investigation in our laboratory, while the compound marked $* *$ has been tentatively identified as a $\mathrm{C}_{8}$ tricarboxylic acid, namely, 3-carboxy-heptanedioic acid, which has been reported in ambient $\mathrm{PM}_{2.5}$ aerosols from a southeastern site in the United States and in a smog chamber experiment with an irradiated $\alpha$-pinene $/ \mathrm{NO}_{\mathrm{x}} /$ air mixture (Edney et al., 2003), and has first been characterized in Amazonian rain forest aerosols (Kubátová et al., 2000).

\subsection{Quantitative data for selected polar organic species}

The concentrations of OC, EC and selected polar organic species in the $\mathrm{PM}_{1}$ samples and meteorological data are given in Table 1. The samples collected from 24 July to 6 
Table 1. Atmospheric concentrations of organic compounds as derived from $\mathrm{PM}_{1}$ samples at Hyytiälä, Finland and meteorological data. Concentrations of OC and EC are in $\mu \mathrm{g} \mathrm{m}^{-3}$ while those of the organic compounds are in $\mathrm{ng} \mathrm{m}^{-3}$. The Means for Summer and Fall are air-volume weighted means.

\begin{tabular}{|c|c|c|c|c|c|c|c|}
\hline \multirow[b]{2}{*}{ Species } & \multicolumn{4}{|c|}{ Summer 2004} & \multicolumn{3}{|c|}{ Fall 2004} \\
\hline & 24-26 July & 26-28 July & 4-6 Aug. & Mean & 22-23 Sep. & 4-8 Oct. & Mean \\
\hline $\mathrm{OC}\left(\mu \mathrm{g} \mathrm{m}^{-3}\right)$ & 2.70 & 2.20 & 4.07 & 2.99 & 1.72 & 1.54 & 1.58 \\
\hline $\mathrm{EC}$ & 0.10 & 0.13 & 0.21 & 0.15 & 0.12 & 0.16 & 0.15 \\
\hline 2-methylthreitol $\left(\mathrm{ng} \mathrm{m}^{-3}\right)$ & 6.05 & 3.50 & 5.71 & 5.08 & 0.17 & 0.18 & 0.18 \\
\hline 2-methylerythritol & 24.3 & 11.6 & 27.6 & 21.2 & 0.32 & 0.28 & 0.29 \\
\hline$\sum 2-$ methyltetrols & 30.4 & 15.1 & 33.3 & 26.3 & 0.49 & 0.46 & 0.46 \\
\hline$\sum \mathrm{C}_{5}$ alkene triols & 33.0 & 7.90 & 29.6 & 23.5 & n.d. & n.d. & n.d. \\
\hline 2-methyl-glyceric acid & 0.95 & 1.19 & 1.15 & 1.10 & n.d. & n.d. & n.d. \\
\hline$\sum$ isoprene oxidation products & 64.3 & 24.2 & 64.1 & 50.9 & 0.49 & 0.46 & 0.46 \\
\hline Malic acid & 40.5 & 38.8 & 59.7 & 46.3 & 4.48 & 5.41 & 5.22 \\
\hline Levoglucosan & 11.8 & 5.71 & 12.3 & 10.0 & 34.3 & 27.8 & 29.1 \\
\hline Glyceric acid & 1.51 & 2.72 & 0.81 & 1.68 & 2.69 & 1.92 & 2.07 \\
\hline Arabitol & 1.15 & 1.15 & 1.71 & 1.34 & 1.73 & 0.55 & 0.79 \\
\hline Mannitol & 1.19 & 1.21 & 3.42 & 1.94 & 1.30 & 0.54 & 0.69 \\
\hline \multicolumn{8}{|l|}{ Meteorological parameters } \\
\hline Average temperature $\left({ }^{\circ} \mathrm{C}\right)$ & 17.2 & 16.9 & 20.8 & 18.5 & 8.2 & 8.4 & 8.3 \\
\hline Maximum temperature $\left({ }^{\circ} \mathrm{C}\right)$ & 22.0 & 21.4 & 26.1 & & 10.2 & 11.6 & \\
\hline Average ozone concentration (ppbv) & 32.8 & 41.9 & 42.5 & 39.1 & 30.2 & 27.6 & 28.1 \\
\hline Maximum ozone concentration (ppbv) & 41.4 & 51.5 & 55.5 & & 39.4 & 35.5 & \\
\hline Total precipitation $(\mathrm{mm})$ & 2.63 & 14.0 & 0 & & 2.61 & 4.23 & \\
\hline
\end{tabular}

August and from 22 September to 8 October are defined as summer and fall samples, respectively. Fall samples are presented as averages of two measurements for 22-23 September and eight measurements for 4-8 October. The OC concentration for the three 48-h samplings during the summer period was on average $3.0 \mu \mathrm{g} \mathrm{m}^{-3}$ and was higher than the OC concentration observed during the fall which was on average $1.6 \mu \mathrm{g} \mathrm{m}^{-3}$. The concentration of the sum of the 2methyltetrols, 2-methylthreitol and 2-methylerythritol, during the summer period was $26 \mathrm{ng} \mathrm{m}^{-3}$. This is comparable to 2-methyltetrol concentrations found during the 2003 summer campaign in K-puszta, Hungary (Ion et al., 2005), and during the LBA-CLAIRE 1998 wet season campaign in Balbina, Brazil (Claeys et al., 2004a): at K-puszta, the median concentration for the sum of the 2-methyltetrols (in the $\mathrm{PM}_{2.5}$ aerosol) was $29 \mathrm{ng} \mathrm{m}^{-3}$, while, at Balbina, this concentration (in the total aerosol) was $31 \mathrm{ng} \mathrm{m}^{-3}$. During the fall period, the atmospheric concentration of the 2-methyltetrols was very low, i.e., $0.46 \mathrm{ng} \mathrm{m}^{-3}$. This can be explained by a seasonal decrease in the isoprene emissions which are temperature- and light-dependent (Sharkey and Yeh, 2001; Jobson et al., 1994; Hakola et al., 2000). Hakola et al. (2003) demonstrated that isoprene concentrations in the ambient air measured in Hyytiälä during a two year period (2001-2002) peaked in July and significantly decreased in the transition from summer to fall. The concentration of the sum of the triol derivatives of isoprene, 2-methyl-1,3,4-trihydroxy-1-butene (cis and trans) and 3-methyl-2,3,4-trihydroxy-1-butene, was $24 \mathrm{ng} \mathrm{m}^{-3}$ and is thus comparable to the concentration of the 2-methyltetrols. It is worth noting that the latter products could not be detected in the fall samples. During the summer period the day-time maximum temperatures and ozone concentrations were quite high (Table 1), which are indicative of high concentrations of photo-oxidants and favorable conditions for fast oxidation of and aerosol formation from isoprene.

The concentration of malic acid based on the three 48$\mathrm{h}$ samplings of the summer period was $46 \mathrm{ng} \mathrm{m}^{-3}$. Similar concentrations of malic acid were measured during the 2003 summer campaign at K-puzsta, Hungary (Ion et al., 2005), where the median concentration (in the $\mathrm{PM}_{2.5}$ aerosol) was $38 \mathrm{ng} \mathrm{m}^{-3}$, during 25-28 July 2001 in Balbina, Brazil (Claeys et al., 2004a), where a concentration (in the total aerosol) of $22 \mathrm{ng} \mathrm{m}^{-3}$ was found, and during 1998 and 1999 summer campaigns at five different sites in Germany (Röhrl and Lammel, 2002), where the average concentration (in the total aerosol) was $64 \mathrm{ng} \mathrm{m}^{-3}$. It can be seen in Table 1 that in the fall period the concentration of malic acid has decreased dramatically to $5.2 \mathrm{ng} \mathrm{m}^{-3}$, consistent with a biogenic origin of malic acid. A similar trend in the malic acid concentrations was reported in the study by Röhrl and Lammel (2002) cited above, where the concentration decreased in fall 


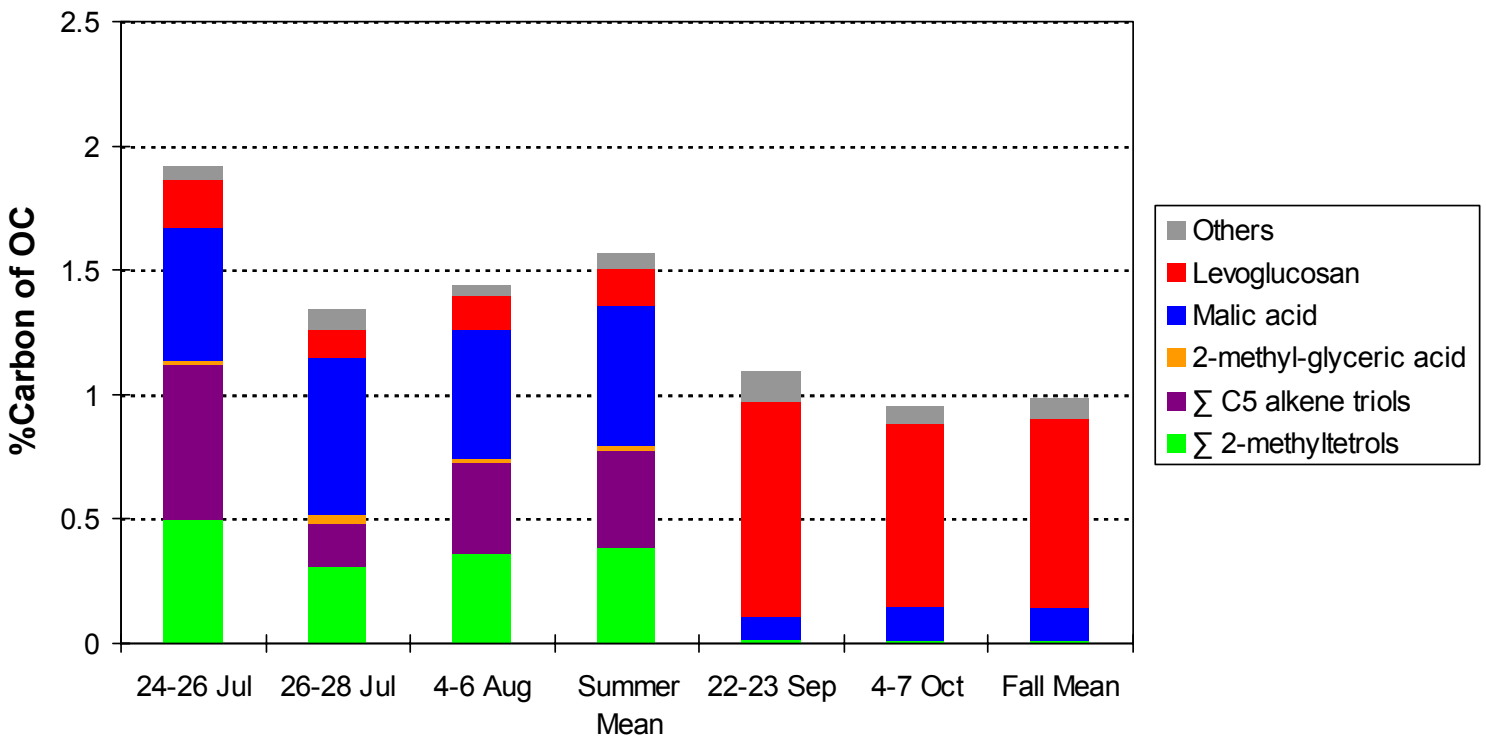

Sample

Fig. 4. Percentages of the $\mathrm{OC}$ attributable to the carbon in the organic compounds, as derived from $\mathrm{PM}_{1}$ aerosol samples collected at Hyytiälä, Finland, during summer and fall periods of 2004. The Means for Summer and Fall are air-volume weighted means.

to $4.8 \mathrm{ng} \mathrm{m}^{-3}$. In contrast, the concentration of levoglucosan increased from $10 \mathrm{ng} \mathrm{m}^{-3}$ during summer to $29 \mathrm{ng} \mathrm{m}^{-3}$ during fall. This result indicates that there is more wood burning in fall compared to summer taking place at or around the station in Hyytiälä. It also explains why the $\mathrm{OC}$ is still relatively high in fall despite a lower impact from oxygenated biogenic VOCs since in addition to levoglucosan there are other organics emitted during the wood burning process (e.g., humiclike substances) that contribute to the OC. A strong seasonal variation in the levoglucosan concentrations with the highest concentrations in winter has been reported for urban $\mathrm{PM}_{10}$ aerosols from Gent, Belgium (Zdráhal et al., 2002; Pashynska et al., 2002).

Figure 4 shows the percentages of the $\mathrm{OC}$ attributable to the carbon in the organic compounds detected in the $\mathrm{PM}_{1}$ aerosol samples collected at Hyytiälä. During the summer period, the oxidation products of isoprene including 2-methyltetrols, alkene triol derivatives of isoprene and 2methylglyceric acid, account for $0.80 \%$, while malic acid and levoglucosan contribute to the $\mathrm{OC}$ with $0.56 \%$ and $0.15 \%$, respectively. During the fall period an inverse trend is observed with levoglucosan, malic acid, and the oxidation products of isoprene contributing to the OC with $0.76 \%, 0.11 \%$ and $0.01 \%$, respectively.

\section{Conclusions and hypothesis for new particle growth}

It can be concluded that photo-oxidation of isoprene is an important atmospheric chemistry process that contributes to secondary aerosol formation during summer at Hyytiälä.
Further research is warranted to explore whether isoprene photochemistry plays a role in new particle formation, a phenomenon which has been well documented for the SMEAR II boreal forest station (Mäkelä et al., 1997; for a recent review, see Kulmala et al., 2004) and is only partially understood (Kulmala, 2003). Significant aerosol nucleation events have been reported in the boreal environment and the biogenic VOCs have been suggested to participate in these processes although direct evidence is still missing (Janson et al., 2001; Boy et al., 2004). Indirect evidence suggesting a role for isoprene in new particle formation has been obtained in two field studies, one conducted at a Canadian boreal forest (Leaitch et al., 1999) and another at a Californian pine forest (Lunden et al., 2005), which showed a co-variance between isoprene emissions and the concentration of ultrafine particles $(<50 \mathrm{~nm}$ and $<20 \mathrm{~nm}$, respectively). Based on results obtained in the current study that isoprene oxidation products are present in boreal forest aerosol at significant concentrations and given that sulfuric acid-water clusters are a source of new atmospheric particles (Kulmala et al., 2000) and sulfuric acid plays a role in the formation of secondary organic aerosol from isoprene (Edney et al., 2005), it is logical to hypothesize that photo-oxidation products of isoprene can form or condense on the initially formed sulfuric acid-water clusters, are subsequently converted to nonvolatile products which through hydrogen bonding interactions are retained in these clusters, and are as such candidate molecules to participate in the initial stages of new particle formation. Another argument in favor of photo-oxidation products of isoprene participating in new particle formation 
is that the 2-methyltetrols and 2-methylglyceric acid exhibit a diel pattern with the highest concentrations during day-time (Ion et al., 2005) when particle burst events are known to occur. It is worth mentioning that heterogeneous reactions of volatile organic vapors occurring on the nuclei have been considered (Kerminen et al., 2000), while heterogeneous reactions with sulfuric acid have been proposed to play a critical role in this process (Zhang and Wexler, 2002). The mechanism proposed here based on heterogeneous chemistry may help the small $\mathrm{nm}$-sized nuclei cross the huge Kelvin-effect barrier and facilitate further condensation of organic vapors. Furthermore, it has been suggested that monoterpene oxidation products are not the nucleating organic species (Marti et al., 1997; Janson et al., 2001) but do contribute to particle growth in forest environments. It is thus tempting to speculate that photo-oxidation products of isoprene play a unique role in the particle nucleation process and "blue haze" formation above forests (Went, 1960).

Acknowledgements. Research at the Universities of Antwerp and Ghent was supported by the Belgian Federal Science Policy Office through the project "Characterization and sources of carbonaceous atmospheric aerosols" (contracts EV/06/11B and EV/02/11A). Research at the University of Helsinki was supported by the Academy of Finland. We would like to thank A. Reissel (Univ. Helsinki) for logistic support, H. Manninen (Univ. Helsinki) for help with the aerosol sampling, and J. Rinne (Univ. Helsinki) for useful discussions.

\section{Edited by: R. Hitzenberger}

\section{References}

Bauer, H., Kasper-Giebl, A., Löflund, M., Giebl, H., Hitzenberger, R., Zibuschka, F., and Puxbaum, H.: The contribution of bacteria and fungal spores to the organic carbon content of cloud water, precipitation and aerosols, Atmos. Res., 64, 109-119, 2002a.

Bauer, H., Kasper-Giebl, A., Zibuschka, F., Hitzenberger, R., Kraus, G. F., and Puxbaum, H.: Determination of the carbon content of airborne fungal spores, Anal. Chem., 74, 91-95, 2002 b.

Bieleski, R. L.: Sugar alcohols, in: Encyclopedia of plant physiology, volume 13A, Plant Carbohydrates, volume I, Intracellular Carbohydrates, edited by: Loewus, A. and Tanner, W., SpringerVerlag, Berlin, pp. 158-170, 1982.

Birch, M. E. and Cary, R. A.: Elemental carbon-based method for monitoring occupational exposures to particulate diesel exhaust, Aerosol Sci. Technol., 25, 221-241, 1996.

Boy, M., Petäjä, T., Dal Maso, M., Rannik, Ü., Rinne, J., Aalto, P., Laaksonen, A., Vaattovaara, P., Joutsensaari, J., Hoffmann, T., Warnke, J., Apostolaki, M., Stephanou, E. G., Tsapakis, M., Kouvarakis, A., Pio, C., Carvalho, A., Römpp, A., Moortgat, G., Spirig, C., Guenther, A., Greenberg, J., Ciccioli, P., and Kulmala, M.: Overview of the field measurement campaign in Hyytiälä, August 2001 in the framework of the EU project OSOA, Atmos. Chem. Phys., 4, 657-678, 2004,

SRef-ID: 1680-7324/acp/2004-4-657.

Brook, J. R., Dabek-Zlotorzynska, E., Lee, P., and Lu, G.: Fine particulate $\mathrm{C}_{1}-\mathrm{C}_{8}$ acids in Toronto and Vancouver, Canada: analysis of a two-year daily time series, Abstracts 8th International Conference on Carbonaceous Particles in the Atmosphere, Vienna, Austria, p. 111, 14-16 September 2004.

Carvalho, A., Pio, C., and Santos, C.: Water-soluble hydroxylated organic compounds in German and Finnish aerosols, Atmos. Environ., 37, 1775-1783, 2003.

Chien, C.-J., Charles, M. J., Sexton, K. G., and Jeffries, H. E.: Analysis of airborne carboxylic acids and phenols as their pentafluorobenzyl derivatives: gas chromatography/ion trap mass spectrometry with a novel chemical ionization reagent, $\mathrm{PFBOH}$, Environ. Sci. Technol., 32, 299-309, 1998.

Claeys, M., Graham, B., Vas, G., Wang, W., Vermeylen, R., Pashynska, V., Cafmeyer, J., Guyon, P., Andreae, M. O., Artaxo, P., and Maenhaut, W.: Formation of secondary organic aerosols through photooxidation of isoprene, Science, 303, 1173-1176, 2004a.

Claeys, M., Wang, W., Ion, A. C., Kourtchev, I., Gelencsér, A., and Maenhaut, W.: Formation of secondary organic aerosols from isoprene and its gas-phase oxidation products through reaction with hydrogen peroxide, Atmos. Environ., 38, 4093-4098, $2004 b$.

Edney, E. O., Kleindienst, T. E., Conver, T. S., McIver, C. D., Corse, E. W., and Weathers, W. S.: Polar organic oxygenates in $\mathrm{PM}_{2.5}$ at a southeastern site in the United States, Atmos. Environ., 37, 3947-3965, 2003.

Edney, E. O., Kleindienst, T. E., Jaoui, M., Lewandowski, M., Offenberg, J. H., Wang, W., and Claeys, M.: Formation of 2-methyl tetrols and 2-methylglyceric acid in secondary organic aerosol from laboratory irradiated isoprene/ $\mathrm{NO}_{\mathrm{x}} / \mathrm{SO}_{2} /$ air mixtures and their detection in ambient $\mathrm{PM}_{2.5}$ samples collected in the eastern United States, Atmos. Environ., 39, 5281-5289, 2005.

Graham, B., Mayol-Bracero, O. L., Guyon, P., Roberts, G. C., Decesari, S., Facchini, M. C., Artaxo, P., Maenhaut, W., Köll, P., and Andreae, M. O.: Water-soluble organic compounds in biomass burning aerosols over Amazonia. 1. Characterization by NMR and GC-MS, J. Geophys. Res., 107(D20), 8047, doi:10.1029/2001JD000336, 2002.

Graham, B., Guyon, P., Taylor, P. E., Artaxo, P., Maenhaut, W., Glovsky, M. M., Flagan, R. C., and Andreae, M. O.: Organic compounds present in the natural Amazonian aerosol: characterization by gas chromatography-mass spectrometry, J. Geophys. Res., 108(D24), 4766, doi:10.1029/2003JD003990, 2003.

Griffin, R. J., Cocker III, D. R., Flagan, R. C., and Seinfeld, J. H.: Organic aerosol formation from the oxidation of biogenic hydrocarbons, J. Geophys. Res., 104, 3555-3567, 1999.

Guenther, A., Hewitt, C. N., Erickson, D., Fall, R., Geron, C., Graedel, T., Harley, P., Klinger, L., Lerdau, M., Mckay, W. A., Pierce, T., Scholes, B., Steinbrecher, R., Tallamraju, R., Taylor, J., and Zimmerman, P.: A global model of natural volatile organic compound emissions, J. Geophys. Res., 100, 8873-8892, 1995.

Hakola, H., Laurila, T., Rinne, J., and Puhto, K.: The ambient concentrations of biogenic hydrocarbons at a Northern European, boreal site, Atmos. Environ., 34, 4971-4982, 2000.

Hakola, H., Tarvainen, V., Laurila, T., Hiltunen, V., Hellén, H., and Keronen, P.: Seasonal variation of VOC concentrations above a boreal coniferous forest, Atmos. Environ., 37, 1623-1634, 2003.

Havers, N., Bandur, R., Lambert, J., and Klockow, D.: Spectroscopic characterization of humic-like substances in airborne particulate matter, J. Atmos. Chem., 29, 45-54, 1998. 
Hjorth, J., Viidanoja, J., Manca, R., Putaud, J.-P., Ferri, D., Jensen, N. R., Astorga, C., Larsen, B., van Dingenen, R., Dell'Acqua, A., Winterhalter, R., and Bolzacchini, E.: Investigation of the $\mathrm{OH}$-initiated oxidation of aromatics in air: Gas phase and condensable products and hygroscopicity of secondary aerosol, in: Transport and Chemical Transformation in the Troposphere, Proceedings of the EUROTRAC Symposium 2002, GarmischPartenkirchen, 11-15 March 2002, edited by: Midgley, P. and Reuther, M., Margraf Verlag, Weikersheim, Germany, CD-ROM, 2002.

Hoffmann, T., Odum, J. R., Bowman, F., Collins, D., Klockow, D., Flagan, R. C., and Seinfeld, J. H.: Formation of organic aerosols from the oxidation of biogenic hydrocarbons, J. Atmos. Chem., 26, 189-222, 1997.

Ion, A. C., Vermeylen, R., Kourtchev, I., Cafmeyer, J., Chi, X., Gelencsér, A., Maenhaut, W., and Claeys, M.: Polar organic compounds in rural $\mathrm{PM}_{2.5}$ aerosols from K-puszta, Hungary, during a 2003 summer field campaign: sources and diel variations, Atmos. Chem. Phys., 5, 1805-1814, 2005,

SRef-ID: 1680-7324/acp/2005-5-1805.

Jang, M. S., Czoschke, N. M., Lee, S., and Kamens, R. M.: Heterogeneous atmospheric aerosol production by acid-catalyzed particle-phase reactions, Science, 298, 814-817, 2002.

Janson, R. and de Serves, C.: Isoprene emissions from boreal wetlands in Scandinavia, J. Geophys. Res., 103, 25 513-25 517, 1998.

Janson, R., de Serves, C., and Romero, R.: Emission of isoprene and carbonyl compounds from a boreal forest and wetland in Sweden, Agr. For. Met., 98/99, 671-681, 1999.

Janson, R., Rosman, K., Karlsson, A., and Hansson, H.-C.: Biogenic emissions and gaseous precursors to forest aerosols, Tellus, 53B, 423-440, 2001.

Janson, R. and de Serves, C.: Acetone and monoterpene emissions from the boreal forest in northern Europe, Atmos. Environ., 35, 4629-4637, 2001.

Jobson, B. T., Wu, Z., Niki, H., and Barrie, L. A.: Seasonal trends of isoprene, $\mathrm{C}_{2}-\mathrm{C}_{5}$ alkanes and acetylene at a remote boreal site in Canada, J. Geophys. Res., 99, 1589-1599, 1994.

Kavouras, I., Mihalopoulos, N., and Stephanou, E. G.: Formation of atmospheric particles from organic acids produced by forests, Nature, 395, 683-686, 1998.

Kavouras, I., Mihalopoulos, N., and Stephanou, E. G.: Formation and gas/particle partitioning of monoterpenes photo-oxidation products over forests, Geophys. Res. Lett., 26, 55-59, 1999.

Kawamura, K. and Ikushima, K.: Seasonal changes in the distribution of dicarboxylic acids in the urban atmosphere, Environ. Sci. Technol., 27, 2227-2235, 1993.

Kawamura, K. and Sakaguchi, F.: Molecular distributions of water soluble dicarboxylic acids in marine aerosols over the Pacific Ocean including tropics, J. Geophys. Res., 104, 3501-3509, 1999.

Kerminen, V.-M., Virkkula, A., Hillamo, R., Wexler, A. S., and Kulmala, M.: Secondary organics and atmospheric cloud condensation nuclei production, J. Geophys. Res., 105, 9255-9264, 2000

Krivacsy, Z., Gelencsér, A., Kiss, G., Mészáros, E., Molnár, A., Hoffer, A., Mészáros, T., Sárvári, Z., Temesi, D., Varga, B., Baltensperger, U., Nyeki, S., and Weingartner, E.: Study on the chemical character of water soluble compounds in fine atmo- spheric aerosol at the Jungfraujoch, J. Atmos. Chem., 39, 235259, 2001.

Kubátová, A., Vermeylen, R., Claeys, M., Cafmeyer, J., Maenhaut, W., Roberts, G., and Artaxo, P.: Carbonaceous aerosol characterization in the Amazon basin, Brasil: novel dicarboxylic acids and related compounds, Atmos. Environ., 34, 5037-5051, 2000.

Kubátová, A., Vermeylen, R., Claeys, M., Cafmeyer, J., and Maenhaut, W.: Organic compounds in urban aerosols from Gent, Belgium: Characterization, sources and seasonal differences, J. Geophys. Res., 107(D21), 8343, doi:10.1029/2001JD000556, 2002.

Kulmala, M., Pirjola, L., and Mäkelä, J. M.: Stable sulphate clusters as a source of new atmospheric particles, Nature, 404, 66-69, 2000.

Kulmala, M., Hämeri, K., Aalto, P. P., Mäkelä, J. M., Pirjola, L., Nilsson, E. D., Buzorius, G., Rannik, U., Dal Maso, M., Seidl, W., Hoffmann, T., Jansson, R., Hansson, H.-C., Viisanen, Y., Laaksonen, A., and O'Dowd, C. D.: Overview of the international project on biogenic aerosol formation in the boreal forest (BIOFOR), Tellus, 53B, 324-343, 2001.

Kulmala, M.: How particles nucleate and grow, Science, 302, 10001001, 2003.

Kulmala, M., Vehkamäki, H., Petäjä, T., Dal Maso, M., Lauri, A., Kerminen, V.-M., Birmili, W., and McMurray, P. H.: Formation and growth rates of ultrafine atmospheric particles: a review of observations, J. Aerosol Sci., 35, 143-176, 2004.

Lamanna, M. S. and Goldstein, A. H.: In situ measurements of $\mathrm{C}_{2}-\mathrm{C}_{10}$ volatile organic compounds above a Sierra Nevada ponderosa pine plantation, J. Geophys. Res., 104, 21 247-21 262, 1999.

Leaitch, W. R., Bottenheim, J. W., Biesenthal, T. A., Li, S.-M., Liu, S. K., Asalian, K., Dryfhout-Clark, H., and Hopper, F.: A case study of gas-to-particle conversion in an eastern Canadian forest, J. Geophys. Res., 104, 8095-8111, 1999.

Limbeck, A., Kulmala, M., and Puxbaum, H.: Secondary organic aerosol formation in the atmosphere via heterogeneous reaction of gaseous isoprene on acidic particles, Geophys. Res. Lett., 30(19), 1996, doi:10.1029/2003GL017738, 2003.

Lunden, M. M., Black, D. R., McKay, M., Revzan, K. L., Goldstein, A. H., and Brown, N. J.: Characteristics of fine particle growth events observed above a forest ecosystem in the Sierra Nevada Mountains of California, Aerosol Sci. Technol., in press, 2005.

Mäkelä, J. M., Aalto, P., Jokinen, V., Pohla, T., Nissinen, A., Palmroth, S., Markkanen, T., Seitsonen, K., Lihavainen, H., and Kulmala, M.: Observations of ultrafine aerosol particle formation and growth in boreal forest, Geophys. Res. Lett., 24, 1219-1222, 1997.

Marti, J. J., Weber, R. J., McMurray, P. H., Eisele, F., Tanner, D., and Jefferson, A.: New particle formation at a remote continental site: Assessing the contributions of $\mathrm{SO}_{2}$ and organic precursors, J. Geophys. Res., 102, 6331-6339, 1997.

Matsunaga, S., Mochida, M., and Kawamura, K.: Growth of organic aerosols by biogenic semi-volatile carbonyls in the forestal atmosphere, Atmos. Environ., 37, 2045-2050, 2003.

Matthias-Maser, S. and Jaenicke, R.: Size distribution of primary biological aerosol particles with radii $\geq 0.2 \mu \mathrm{m}$, Atmos. Res., 39 , 279-286, 1995.

Neusüss, C., Pelzing, M., Plewka, A., and Herrmann, H.: A new analytical approach for size-resolved speciation of organic com- 
pounds in atmospheric aerosol particles: Methods and first results, J. Geophys. Res., 105, 4513-4527, 2000.

Pandis, S. N., Paulson, S. E., Seinfeld, J. H., and Flagan, R. C.: Aerosol formation in the photooxidation of isoprene and $\beta$ pinene, Atmos. Environ., 25A, 997-1008, 1991.

Pashynska, V., Vermeylen, R., Vas, G., Maenhaut, W., and Claeys, M.: Development of a gas chromatography/ion trap mass spectrometry method for determination of levoglucosan and saccharidic compounds in atmospheric aerosols: Application to urban aerosols, J. Mass Spectrom., 37, 1249-1527, 2002.

Pierrotti, D., Wofsy, S. C., Jacob, D., and Rasmussen, R. A.: Isoprene and its oxidation products: methacrolein and methyl vinyl ketone, J. Geophys. Res., 95, 1871-1881, 1990.

Pio, C., Alves, C., and Duarte, A.: Organic components in a forested area of central Greece, Atmos. Environ., 35, 389-401, 2001.

Röhrl, A. and Lammel, G.: Determination of malic acid and other $\mathrm{C}_{4}$ dicarboxylic acids in atmospheric aerosol samples, Chemosphere, 46, 1195-1199, 2002.

Rogge, W. F., Hildemann, L. M., Mazurek, M. A., Cass, G. R., and Simoneit, B. R. T.: Quantification of urban organic aerosols at a molecular level: identification, abundance and seasonal variation, Atmos. Environ., 27, 1309-1330, 1993.

Sharkey, T. D. and Yeh, S.: Isoprene emission from plants, Annu. Rev. Plant Mol. Biol., 52, 407-436, 2001.

Shafizadeh, F.: The chemistry of pyrolysis and combustion, in: Chemistry of Solid Wood, edited by: Rowell, R., Advances in Chemistry Series 207, American Chemical Society, Washington D.C., pp. 489-529, 1984.

Simoneit, B. R. T.: Biomass burning - a review of organic tracers for smoke from incomplete combustion, Applied Geochem., 17, 129-162, 2002.
Vesala, T., Haataja, J., Aalto, P., Altimir, N., Buzorius, G., Garam, E., Hämeri, K., Ilvesniemi, H., Jokinen, V., Keronen, P., Lahti, T., Markkanen, T., Mäkelä, J. M., Nikinmaa, E., Palmroth, S., Palva, L., Pohja, T., Pumpanen, J., Rannik, Ü., Siivola, E., Ylitalo, H., Hari, P., and Kulmala, M.: Long-term field measurements of atmosphere-surface interactions in boreal forest combining forest ecology, micrometeorology, aerosol physics and atmospheric chemistry, Trends in Heat, Mass \& Momentum Transfer, 4, 1735, 1998.

Wang, W., Kourtchev, I., Graham, B., Cafmeyer, J., Maenhaut, W., and Claeys, M.: Characterization of oxygenated derivatives of isoprene related to 2-methyltetrols in Amazonian aerosols using trimethylsilylation and gas chromatography/ion trap mass spectrometry, Rapid Commun. Mass Spectrom., 19, 1343-1351, 2005.

Went, F. W.: Blue hazes in the atmosphere, Nature, 187, 641-643, 1960.

Yu, J., Griffin, R. J., Cocker III, D. R., Flagan, R. C., Seinfeld, J. H., and Blanchard, P.: Observation of gaseous and particulate products of monoterpene oxidation in forest atmospheres, Geophys. Res. Lett., 26, 1145-1148, 1999.

Zdráhal, Z., Oliveira, J., Vermeylen, R., Claeys, M., and Maenhaut, W.: Improved method for quantifying levoglucosan and related monosaccharide anhydrides in atmospheric aerosols and application to samples from urban and tropical locations, Environ. Sci. Technol., 36, 747-753, 2002.

Zhang, K. M. and Wexler, A. S.: A hypothesis for growth of fresh atmospheric nuclei, J. Geophys. Res., 107(D21), 4577, doi:10.1029/2002JD002180, 2002.

Zheng, M., Cass, G. R., Schauer, J. J., and Edgerton, E. S.: Source apportionment of $\mathrm{PM}_{2.5}$ in the southeastern United States using solvent-extractable organic compounds as tracers, Environ. Sci. Technol., 36, 2361-2371, 2002. 